This is the version of the chapter accepted for publication in Authoritarian Constitutionalism: Comparative Analysis and Critique published by Edward Elgar https://doi.org/10.4337/9781788117852.00018

\title{
Arab Constitutionalism
}

\section{and the Formalism of Authoritarian Constitutionalism}

\section{Nimer Sultany}

This chapter challenges different manifestations of a "formalist" approach to constitutional theory. ${ }^{1}$ The formalist approach deploys several labels and distinctions (constitutions without constitutionalism, authoritarian, ideological, instrumentalist, and temporary) that question the constitutional legitimacy of nonNorth American and non-Western European constitutions because these are considered as merely political instruments lacking the supremacy and rigidity of higher law. This approach is formalist in two senses: it is overly focused on the text (or constitutional form), and it assumes that abstract categories determine the constitutional content or practice. Ottoman and Arab constitution-making, the subject of this chapter, illustrate that this formalist approach is deficient because it is impervious to constitutional and political practice. As such, and while "ideological" is often used in the "positive sense" to convey a system of ideas, it has negative "ideological" effects because it juxtaposes these constitutions to an idealised version of liberal constitutions (understood as “normative”, supra-political constitutions) and discounts constitutional experiences that fall outside the orbit of North America and Europe.

This chapter is organized as follows. The first section presents the general argument by focusing on the notion of "constitutions without constitutionalism". The second section zeros in on the notion of "authoritarian constitutionalism" and the third and fourth sections scrutinize its accompanying subcategories “ideological”, “instrumental”, and “temporary” constitutions. It is argued that these categories are neither analytically illuminating nor descriptively informative. Arab constitutions served different purposes,

\footnotetext{
1 This chapter is an abridged and revised version of chapters 2 and 3 in Sultany, Nimer (2017) Law and Revolution: Legitimacy and Constitutionalism After the Arab Spring, Oxford: Oxford University Press.
} 
included inconsistencies, and provided a space for political struggle and contestation. Thus, these abstract categories foreclose a nuanced and properly contextualized analysis of post-colonial constitutional orders. The final section, the Conclusion, elaborates on the framing effects of these abstract categories.

\section{ARAB CONSTITUTIONS WITHOUT CONSTITUTIONALISM?}

Scholars of Arab constitutions describe them as “constitutions without constitutionalism”. This label often implies that constitutions’ primary purpose was to provide sociological and legal legitimation for political regimes rather than a normative legitimation in the form of liberal constitutionalism ("limited and accountable government”). ${ }^{2}$ This is because Arab constitutions often failed to impose effective limits on the exercise of executive power and defend basic rights. Additionally, Arab constitutions are often described as “elitist" because they did not express popular will. Specifically, the late $19^{\text {th }}$ and early $20^{\text {th }}$ century constitutions exemplified “elitist constitutionalism”, in which constitutions were negotiated amongst elites. ${ }^{3}$ Similarly, the post-colonial constitutions are considered as instances of “authoritarian constitutionalism”, in which executive power granted the constitution without genuine popular involvement or sustained popular support and sought to impose top-down modernization. According to this pre-Arab Spring, elite-centered reading of Arab constitutional history: “Arab constitutionalism is far more likely to emerge from institutional balancing and elite bargains than it is from any authentic form of popular sovereignty”. ${ }^{4}$

In light of this, some scholars maintain that the reason for the relevance of Arab constitutions (as opposed to being a "façade" or "sham”) is not because they serve constitutionalist roles but precisely because of their "non-constitutionalist” roles. Scholars are often content with pointing out the logistical and formal roles that non-constitutionalist constitutions may serve. Constitutionalism is thus reduced to "strategic constitutionalism" that is designed to serve but not limit government. In the absence of a normative (constitutionalist) or a democratic role, Nathan Brown argues, the Arab constitutions served primarily an "enabling” function of sociological legitimation ("to render the political authority of the state

\footnotetext{
2 Brown, Nathan J. (2001) Constitutions in a Nonconstitutional World: Arab Basic Laws and the Prospects for Accountable Government, Albany: SUNY Press, xiv, 9-10.

${ }^{3}$ Abdul Fattah, Saif Al-Din (2014) 'Al-Dustur al-Misri bayna Masarat al-Ta'wil wa-l-Ta'dil wa-l-Taf'il: Ru'ya min Manzur alTawafuq Al-Siyasi' in: Jadal al-Dustur wa-l-Marhala al-Intiqaliyya fi Misr bayna 25 Yanayar wa 30 Yuniu, Beirut: Al-Markaz al-'Arabi li-l-'Abhas wa Dirasat al-Siyasat 101.

${ }^{4}$ Brown, Constitutions in a Nonconstitutional World xiv.
} 
more effective" and "stable"). They also served secondary "symbolic" (to declare independence and pronounce state sovereignty) and "ideological" purposes (to assert the regime's general ideological orientation). ${ }^{5}$ From this perspective, it is unsurprising that Arab regimes engaged in extensive constitutionmaking. Even repressive regimes look less arbitrary and whimsical when they exercise power through the routine and impersonal application of the law and in accordance with a set of governing norms. ${ }^{6}$ Constitutions may even empower autocratic rulers by allowing an efficient and more rational political-legal order. ${ }^{7}$

The reason for the relevance and importance of these constitutions is different, however. These constitutions were embedded in social and intellectual processes that had real salience. These processes cannot be explained by reference to the role of elites only. Despite elites' attempt to create democracy without demos it still created a language and augmented political culture. Even if this was a contradictory project and fell short of its promises, it still expanded the political horizon. The primary difficulty with approaches to "strategic constitutionalism" is thus twofold. On the one hand, constitutions cannot be reduced to their state-empowering function. The fact that constitutions serve a contradictory role—simultaneously limiting and empowering - opens spaces for political contestation. On the other hand, from the gap between “constitutions” and “constitutionalism” it does not follow that constitutions' role can be assessed only through a focus on constitutional documents without considering the effect of constitutional ideas and their social purchase. As the debates around the Tunisian, Egyptian, and Ottoman constitutional experiments in the second half of $19^{\text {th }}$ century show, the rationalisation of the mode of government was not merely a question of sociological efficacy but also intertwined with normative discussions about the values that should govern society, the authenticity/ Islamicity of legal "implants”, and the standing of Arab and Muslim societies in the world. Thus, these constitutions operated as a site for political and legal contestation in which differently situated parties accepted them for different reasons, placed on them conflicting hopes, and utilised them in a variety of ways. This contestation is possible because these constitutions were often a

\footnotetext{
${ }^{5}$ Brown, Constitutions in a Nonconstitutional World xiv, 10-13.

${ }^{6}$ Salamé, Ghassan (2011) Nahwu 'Aqd 'Ijtima'i 'Arabi Jadid (Bahth fi al-Shar'iyya al-Dusturiyya), 2nd edn, Beirut: Markaz Dirasat al-Wihda al-'Arabiyya, 50-51.

${ }^{7}$ Brown, Constitutions in a Nonconstitutional World: 11; Holmes, Stephen (2012) 'Constitutions and Constitutionalism' in Michel Rosenfeld and András Sajó eds, The Oxford Handbook of Comparative Constitutional Law, Oxford: Oxford University Press 198.
} 
product of a compromise or modus vivendi and thus their content was indeterminate. Consequently, the changing circumstances around these constitutions influenced their effects. The "temporariness" and “contingency” features of modus vivendi do not imply lack of normativity.

In addition, the reduction of constitutions to sociological legitimation is not explicable by reference to a set of coherent and stable purposes. The different purposes that constitutions may serve are interlinked and one cannot disentangle the legitimating effect from the intended or unintended effects it may have. First, the "enabling” and "ideological” roles were elusive because the "state” is not a coherent unit and its ideology is not homogenous. This incoherence did not only exist in the early stages of state building and formation under Ottoman and colonial rule. The "ideological” goal influenced the "enabling” goal after independence because the social transformative agenda of Arab republican states influenced their institutional organisation. “Ideological” disagreements and changes were accompanied by changes in political and legal organisation. Secondly, the multiple usages and competing meanings of "sovereignty" (i.e. its indeterminacy) illustrate that its constitutionalisation is not merely "symbolic" but also plays an "ideological” role and its effects may be "enabling" or constraining to state power. Constitutional declarations of sovereignty existed in precolonial and post-colonial constitutions and thus reflected different degrees of its attainment (or different gaps between its proclamation and its actual effect). It was also manifested in formal colonial constitutions (Under British and French occupations), as much as in informal anti-colonial constitutions that challenged centralised colonial sovereignty and presented multiple sovereignties in revolutionary struggles (such as the 1919 Syrian constitutional draft, the 1918 Libyan Republican Constitution, and the 1921 Moroccan constitution). Finally, whether under colonial or post-colonial constitutions, the enabling goal of "state sovereignty" occasionally conflicted with the "ideological” and legitimating goal of "popular sovereignty". In both cases, constitutions were rarely a mere top-down imposition by, or instruments in the hands of, rulers.

The preceding suggests that the label “constitutions without constitutionalism” is misleading if it suggests that Arab constitutions merely served a strategic function or provided sociological legitimacy. It is also misleading if it further implies that the closure of this gap between constitutions and constitutionalism (and hence the achievement of a "constitution as a contract for legitimacy") would normatively legitimate 
Arab regimes. This is because the normative constitution is too abstract and controversial to generate a universally accepted legitimation, ${ }^{8}$ and “democratic constitutionalism” is a paradoxical notion that pits rights against majorities. ${ }^{9}$ In other the words, the supposed distinction between "constitutionalist" and "nonconstitutionalist” constitutions is questionable. It wrongly implies that "constitutionalist constitutions” would be free from abstraction, manipulation, instrumentalisation, incoherence, and contradiction.

The assessment of Arab constitutions' contribution to legitimacy has to consider these constitutions in practice, i.e., the "totality" of the political-legal order. As this totality is always work-in-progress, this legitimacy is always unstable and incomplete. In this sense, the failings of Arab constitutions are a specific example of the general condition of constitutions. The exclusion of majorities and the gap between validation and normative legitimation, illustrate that Arab constitutions did not provide the regimes with an approximation to legitimacy (legitimation-worthiness). Nevertheless, the democratic or normative deficiency of Arab constitution-making does not to suggest that Arab regimes were illegitimate in accordance with some consensual standard, because no regime can realise legitimacy in this sense, because no such standard exists. Thus, the failure of these constitutions does not stem from their reduction to sociological legitimation: First, because they have always already included normative elements whose efficacy varied depending on context. Second, because an increase in their normative role would not have guaranteed a more successful normative legitimation. Therefore, the distinction between “constitutions without constitutionalism” and normative constitutions (that can serve as "contracts for legitimacy”) is overstated; it cleanses the former from the normative and the latter from the sociological. ${ }^{10}$

An examination of early constitutional experiments and colonial constitutions in the Arab world illustrates the preceding points. They showcase the persistent demand for a constitutional form of government in which constitutional documents seek not only to rationalise government by limiting absolute power, but also to mediate the demand for self-rule and subsequently popular sovereignty. This mediation led to internal contradictions and tensions. On the one hand, this tension originates in the fact that many of

\footnotetext{
${ }^{8}$ Michelman, Frank I. (2003) 'Is the Constitution a Contract for Legitimacy?' 8(2) Review of Constitutional Studies 101.

${ }^{9}$ Sultany, Nimer (2012) 'The State of Progressive Constitutional Theory: The Paradox of Constitutional Democracy and the Project of Political Justification', 47 Harvard Civil Rights-Civil Liberties Law Review 371.

10 For a critique of the reduction of the variety of constitutional experiences to the "higher law" model see GonzálezJácome, Jorge (2017) 'From abusive constitutionalism to a multilayered understanding of constitutionalism: Lessons from Latin America' 15 International Journal of Constitutional Law 447.
} 
these early constitutional documents were a product of a compromise even though they were formally a "grant” from the ruler (e.g., the 1876 Ottoman Constitution or the 1923 Egyptian Constitution). On the other hand, further tensions resulted from foreign encroachment and British and French colonial occupations. As such, despite their democratic and normative limitations, these constitutions cannot be reduced to a singular legitimating function nor can they be easily dismissed as a parchment barrier.

Thus, what may be troublesome about pre-independence constitutions is not their codification of political and economic weakness, because they also represented a reaction to it and an attempt to overcome it. Nor are they troubling because their elitism evaded a normative foundation for the political community, because this alleged lack of normative foundation underestimates the fact that $19^{\text {th }}$ century and $20^{\text {th }}$ century constitutions were at the center of normative contestation. This contestation is neither repudiated by the elitism of constitution-making nor reducible to a narrowly defined political system that is separated from the wider cultural context.

Rather, these constitutions were problematic because of the fetishism of constitutionalism. Burhan Ghalyun, for instance, highlights the reductionism of the $19^{\text {th }}$ century reform agenda to the constitution. The fixation on the constitution makes it a "fetish" as it bestows on the constitution powers it does not necessarily have. ${ }^{11}$ Likewise, Devereux states that the constitutionalists who argued for the 1876 Ottoman Constitution saw in it "the best hope for the regeneration of the Empire” and believed that the establishment of a constitutional form of government would "restore to their country its vanished strength and vigor" and hence wanted to “obtain a constitution—any constitution”. ${ }^{12}$ The Arab reformers had high expectations from the revival of the Ottoman Constitution in 1908. They argued for a "representative" system in which the nation "governs itself by itself" and endowed the constitution with their desire for modernisation, rationalisation, and independence. ${ }^{13}$ In this sense, constitutionalisation may actually hamper reform efforts through a misguided orientation.

\section{POST-COLONIAL AUTHORITARIAN CONSTITUTIONALISM}

\footnotetext{
${ }^{11}$ Ghalyun, Burhan (1986) Bayan min Ajl al-Dimuqratiyya, 4th edn, Beirut: Mu'assasat Al-Abhath Al-'Arabiyya, 38.

12 Devereux, Robert (1963) The First Ottoman Constitutional Period: A Study of the Midhat Constitution and Parliament, Baltimore: The Johns Hopkins Press, 28.

13 Al-Bustani, Suleiman (2014) Al-Dawla Al-'Uthmaniyya Qabl Al-Dustur wa Ba'dah, Cairo: Hindawi, 18.
} 
"Authoritarian constitutionalism" is one of the primary categories that exemplify the phenomenon of “constitutions without constitutionalism.” Post-colonial constitutions in the Arab world (such as Egypt after 1952 and Algeria after 1962) are variously and pejoratively described in the literature as "authoritarian," “ideological," and "instrumentalist” given the large-scale social transformations that post-colonial rulers advanced. These labels question the legitimacy of Arab constitutions because they are perceived as political rather than supra-political. “Constitutional legitimacy” requires constitutional "supremacy,” according to which the constitution is the highest norm and the source of all powers. In turn, supremacy requires constitutional entrenchment or rigidity through the requirement of a higher threshold for constitutional amendment in order to set the constitution as higher law apart from ordinary law-making. It also requires establishing institutional guarantees for the subordination of ordinary legislation to the constitution in the form of judicial review. ${ }^{14}$

In order to assess constitutional legitimacy in practice, however, it is necessary to critically assess labels these labels because they pre-empt a nuanced examination and reduce constitutions to sociological legitimation or strategic functions. It is necessary to overcome a common dismissal of many of these constitutions as merely "ideological” or "instrumental” at the service of an all-encompassing "authoritarian” regime. This dismissal is misconceived because it caricatures these constitutions by reducing them into a singular function or effect, and is misleading because it obscures their similarity to other "non-ideological" constitutional configurations. Moreover, it rests on untenable assumptions about "law," "instrumentalism," and the role of "ideology." In particular, law appears as over-determined, coherent, gapless, and free of agency and political struggles.

Authoritarian states are highly centralized and seek to control the social field and to monopolize the political system. Yet, this control is incomplete, and the state is not as coherent or omnipotent as the regime wishes to present it. ${ }^{15}$ Thus, scholars point out that the "authoritarian” state is not a "totalitarian” state and

\footnotetext{
${ }^{14}$ Abbes, Ammar (2013) 'Daur al-Majlis al-Dusturi al-Jaza'iri fi Daman Mabda' Sumuw al-Dustur' 1 Majalla al-Majlis alDusturi 55, 59-61.

15 Owen, Roger (2000) State, Power and Politics in the Making of the Modern Middle East, 2nd edn, Routledge, $31,35$.
} 
thus it needs to combine methods of coercion, consent, and cooptation. ${ }^{16}$ In fact, even a "totalitarian" state may not be wholly coherent and omnipotent. ${ }^{17}$

Therefore, authoritarian rulers’ recourse to constitution-making is not a mere façade. Rather, they are motivated by a variety of institutional, political, legal, and normative considerations. Constitutions can address some of the challenges of coordination, control, and civilian cooperation. ${ }^{18}$ The "enactment of a new constitution signals the intention of a dictatorship to institutionalise its rule." ${ }^{19}$ The establishment of a new constitution is even more crucial for military rulers who have a large-scale transformative agenda. ${ }^{20}$ This transformative agenda requires justifications for a long-term rule. Hence, Negretto argues, authoritarian constitutions seek to solidify the military's rule by integrating a variety of actors in the process; to immunize their policies by constraining future democratic governments; to regulate the exercise of power; to provide the regime with a legal basis that would impose a duty to obey on citizens; and, finally, to facilitate international recognition. ${ }^{21}$ However, the leaders' failure to maintain popular mobilization in support of their rule and constitutions undermines their ability to achieve their goals. ${ }^{22}$

Even when authoritarian constitutions are not designed to limit executive power and protect individual rights, they cannot be easily dismissed as "sham” constitutions. In addition to delineating the institutional design or promulgating the rulers’ ideology, they may have far-reaching consequences. As Scott Newton shows with respect to Soviet constitutions, the "autonomies" and "nationalities" that these constitutions created became "fully institutionalised forms of life" that were internalized by citizens, shaped their individual and collective identities, were mobilized for nationalist claims, and influenced the postSoviet republics. ${ }^{23}$ Although these constitutions were neither supreme nor justiciable, and the judiciary was weak, they provided for an institutional protection of rights. ${ }^{24}$

\footnotetext{
16 Owen, State, Power and Politics 31-32; Ayubi, Nazih H. (1995) Over-Stating the Arab State: Politics and Society in the Middle East, I.B. Tauris, 206; Trubek, David M. (1972) 'Toward a Social Theory of Law: An Essay on the Study of Law and Development' 82 Yale Law Journal 1, 35, 37.

17 Neumann, Franz (2009), Behemoth: The Structure and Practice of National Socialism, 1933-1944, Ivan R. Dee, 41-82.

18 Ginsburg, Tom and Simpser, Alberto (2014), 'Introduction' in Tom Ginsburg and Alberto Simpser eds, Constitutions in Authoritarian Regimes, Cambridge: Cambridge University Press 2.

${ }^{19}$ Negretto, Gabriel L. (2014) 'Authoritarian Constitution Making: The Role of the Military in Latin America' in Ginsburg, Tom and Simpser, Alberto eds, Constitutions in Authoritarian Regimes, Cambridge: Cambridge University Press 83, 87.

${ }^{20}$ Negretto, 'Authoritarian Constitution Making' 83.

${ }^{21}$ Negretto, 'Authoritarian Constitution Making' 90.

22 Negretto, 'Authoritarian Constitution Making' 83.

${ }^{23}$ Newton, Scott (2017) The Constitutional Systems of the Independent Central Asian States: A Contextual Analysis, Oxford: Hart, 67.

24 Newton, The Constitutional Systems 69-82.
} 
The second half of the twentieth century witnessed the proliferation of authoritarian constitutions in Arab states. With the important exceptions of Saudi Arabia (until 1992) and Oman (until 1996), these were written and codified constitutions. ${ }^{25}$ As such, Arab constitutions were consistent with global constitutional trends that witnessed an expansion of written constitutions after 1945. Influenced by the colonial past, postcolonial constitutions largely followed a form of governance that resembled that of the former French or British colonial power. ${ }^{26}$ For the most part, these post-independence constitutions were displaced or rewritten to reflect national and transnational changes during and after the 1980s. These formal changes include: a move away from socialism to liberalism, from single-party rule to political pluralism, as well as an expanded lists of rights and popular election of presidents. ${ }^{27}$

This focus, however, on written texts and formal arrangements conceals more than it reveals. In particular, a formal reading misses the non-formal and non-textual forms of constitutional change (such as judicial interpretation or the changing sociological meanings that underlie constitutional texts) or the gap between text and practice. ${ }^{28}$ For instance, Egypt ceased to be a “socialist” economy long before a constitutional amendment removed the word socialism from the constitutional text in 2007.

Consider further the argument that constitutions’ weak normative status is reflected in the fact that even when some of the Arab constitutions enumerated a limited list of liberal rights, these very rights were often qualified or followed by the proviso that they can be regulated in accordance with conditions "set forth by the law” (as in the 1876 Ottoman Constitution or Egypt's 1923 and Iraq’s 1925 constitutions). ${ }^{29}$ In other words, constitutional rights were amenable for derogation through ordinary legislation. This criticism is an additional example of the misguided formalist-textualist approach in constitutional law that separates between text and practice (its interpretation and application). The Egyptian courts, for instance, have long maintained that the license to regulate rights does not mean a license to violate rights and that the

\footnotetext{
${ }^{25}$ See, e.g., Aba-Namay, Rashed (1993) 'The Recent Constitutional Reforms in Saudi Arabia' 42(2) The International and Comparative Law Quarterly 295.

${ }^{26}$ Go, Julian (2007) 'A Globalizing Constitutionalism? View from the Post-Colony, 1945-2000' in Arjomand, Saïd ed, Constitutionalism and Political Reconstruction, Brill, 89, 90, 92.

27 Go 'A Globalizing Constitutionalism?' 97-103.

${ }^{28}$ Schauer, Frederick (1995) 'Amending the Presuppositions of a Constitution' in Levinson, Sanford ed, Responding to Imperfection: The Theory and Practice of Constitutional Amendment, Princeton University Press.

${ }^{29}$ Brown, Nathan J. (2007) 'Regimes Reinventing Themselves: Constitutional Development in the Arab World' in Arjomand, Said Amir ed, Constitutionalism and Political Reconstruction, Boston, MA: Brill, 54; Devereux, The First Ottoman Constitutional Period 75; Davidson, Nigel G. (1925) 'The Constitution of Iraq' 7(1) Journal of Comparative Legislation and International Law 41, 45.
} 
constitutional stipulation of rights requires legislative regulation to advance the right rather than undermine it and empty it from content. ${ }^{30}$

These critiques posit a false dichotomy between modus vivendi and normativity. ${ }^{31}$ They thus exaggerate the role of normativity as if it were separate from social and political conflict, and dismiss modus vivendi as if it were free of normative considerations. However, normative endorsement can be consistent with modus vivendi because it permits a wide range of political disagreement because principles are abstract, open for interpretation, and thus controversial. Consequently, a normative commitment does not eliminate political and social conflict and does not secure constitutional durability. On the other hand, the efficacy of rights does not merely rely on formal guarantees in a written constitution but on the political and social struggles that make these rights possible and shape their meaning in concrete ways. Consequently, the weakness of a constitution cannot be attributed to its form (that the drafters neglected to make rights nonqualified) or to the lack of normative basis (that the political actors' support to the constitution was purely instrumentalist). Finally, whether the constitution is based on a modus vivendi or a normative endorsement it still maintains a gap between constitutionality (validity) and normative legitimacy because it does not secure the ongoing conformity of the political-legal regime with standards that everyone would consent to. In other words, in each particular moment citizens and political actors need to decide whether they consider the constitution as respect-worthy given the context in which they operate.

\section{IDEOLOGY AND LEGAL INSTRUMENTALISM}

The normative weakness of post-colonial Arab constitutions does not necessarily stem from the “ideological” and "instrumentalist” character of these constitutions. Scholars emphasize the role of legal instrumentalism in maintaining authoritarian modernization. This conception of the law as a means to an end seems congenial to authoritarian tendencies as the rulers seek to control the legal system and undermine its

\footnotetext{
30 See, e.g., Supreme Constitutional Court, Case 82, Judicial Year 26, Ahmad Wahid Al-Din 'Ali v. The Prime Minister and the Legal Representative of the National Commission for Social Security (delivered on 5 August 2012), published in Official Gazette, no. 32 bis (a) (15 August 2012) 3; Supreme Constitutional Court, Case 119, Judicial Year 30, 'Atyya 'Ali 'Ali Ahmad v. The Prime Minister et al (delivered on 7 April 2013), published in Official Gazette, no. 15 bis (b) (17 April 2013 ); Supreme Constitutional Court, Case 150, Judicial Year 31, 'Abd Al-Aziz 'Abd Al-Basir Ahmad v. Speaker of Parliament et al (delivered on 12 October 2014), published in Official Gazette, no. 34 (23 October 2014) 3.

31 For an example of a binary dichotomy between the "normative" and the "prerogative" spheres, see Fraenkel, Ernst (2017) The Dual State: A Contribution to the Theory of Dictatorship, Oxford: Oxford University Press.
} 
autonomy. For this purpose, first, instrumentalism centralizes the bureaucratic state as the source of legal norms; second, the rulers legalize political issues to depoliticize them (and hence exclude political participation); third, they politicize the judiciary and legal professional associations to minimize conflict with them. ${ }^{32}$

Whereas this may well be the authoritarian conception of the law, it does not provide an assessment of the role of law under authoritarian constitutions. Such an assessment requires an evaluation of the struggle between competing notions of law and recognizing the law’s indeterminacy rather than reducing the law to a mere servant. For example, Yash Ghai argues that the primary role of the state in accumulation undermined constitutionalism as it manifested endemic corruption and summoned a repressive rule. ${ }^{33}$ The authoritarian state deployed an instrumental conception of law and constitutions, according to which the law was merely the servant of politics and had no intrinsic value or autonomous existence. ${ }^{34}$ Thus, constitutions were part and parcel of the rationalization and centralization of state power. Consequently, it is argued that these are “ideological constitutions" that embraced developmentalism, and were an "instrument” of social transformation rather than a limitation on governmental power or a protection of individual rights. ${ }^{35}$ The "ideological” constitution is distinctive, Brown argues, because "its ideological and programmatic nature overwhelms its substantive and procedural content." ${ }^{36}$ Thus, the post-colonial nation-state in many developing countries emerged as a "patrimonial state, with highly personalised authority ... on the legal foundations of a constitutionalist state." ${ }^{37}$ In other words, for these scholars, the "ideological” label conveys a politicized and substantive constitution.

Admittedly, the revolutionary post-colonial constitutions are by no means liberal or neutral or procedural. They are closer to the communitarian and republican model that rejects the pretense of liberal proceduralism. The republican model sets collective goals, requires virtue, and favors mass participation. ${ }^{38}$ “Ideological” and revolutionary legitimacy becomes crucial in the absence of legitimation based on the

\footnotetext{
32 Trubek, 'Toward a Social Theory of Law' 35-39.

33 Ghai, Yash (1991) 'The Theory of the State in the Third World and the Problem of Constitutionalism' 6 Connecticut Journal of International Law 411, 418-21.

${ }^{34}$ Ghai, 'The Theory of the State' 418-421.

35 Arjomand, Saïd Amir (2007) 'Constitutional Development and Political Reconstruction from Nation-building to New Constitutionalism' in Arjomand, Saïd Amir ed, Constitutionalism and Political Reconstruction, Albany: SUNY, 7-9.

36 Brown, Constitutions in a Nonconstitutional World, 11.

37 Ghai, 'The Theory of the State' 422.

38 Gargarella, Roberto (2012) “The Constitution and Justice” in Rosenfeld, Michel and Sajó, András eds, The Oxford Handbook of Comparative Constitutional Law, Oxford: Oxford University Press, 336, 345.
} 
"divine rights of kings" and the desire to minimize or avoid religious legitimation given the mostly secular approach of the revolutionary regimes. No wonder, then, that those revolutionary constitutions enshrine revolutionary ideals and boast of revolutionary achievements. They become part and parcel of the machinery to mobilize the people and guarantee their continued support. Yet, in the course of doing so constitutionmakers risk reducing constitutions into a mere pamphlet or manifesto. ${ }^{39}$ While the manifesto is one of the many respectable historical functions of constitutions, ${ }^{40}$ if the constitution is popularly understood to be no more than a political declaration that lacks legal effects then it may not contribute to the regime's quest to gain popular respect or generate collective mobilisation. "Ideological" legitimation, therefore, may undermine the potential sociological legitimation of these constitutions as much as it may strengthen it, because it may decrease their utility and undermine their standing. Thus, the effects of such "ideological" legitimation are indeterminate and may unevenly impact different social groups.

The assessment that these constitutions are "ideological” and served as mere "instruments" is not compelling or particularly revealing for additional reasons. Modern law contains an irreducible conflict between autonomy and instrumentalism, and any attempt to conceptualize the law and understand its role in society by reference to either side of this internal conflict is misleading. ${ }^{41}$ Instrumentalism, as a matter of legal theory, can neither imply that the law is merely a coercive command nor that it is reducible to its instrumentality. ${ }^{42}$ Scott Newton argues that even at the height of legal instrumentalism during Soviet modernization, the experiment merely confirmed the centrality of law and the limitations of instrumentalism. The Soviet practice vacillated between different emphases, failed to eradicate the interior aspect of legal reasoning, and, despite collectivism, private and personal rights remained highly influential. ${ }^{43}$ Despite all its efforts at harmonization and modernization, the Soviet constitutional order failed to achieve unity or

\footnotetext{
${ }^{39}$ Farahat, Muhammad Nur and Farahat, Umar (2011), Al-Tarikh al-Dusturi al-Misri: Qira'a min Manzur Thawrat Yanayir 2011, Al-Dar Al-'Arabiyya li-l-'Ulum Nashirun wa Markaz Al-Jazeera li-l-Dirasat 2011) 68 (referring to Egypt's 1964 temporary constitution as a "political declaration").

${ }^{40}$ Frankenberg, Günter (2006) 'Comparing constitutions: Ideas, ideals, and ideology—toward a layered narrative' 4(3) International Journal of Constitutional Law 439, 452-453.

${ }^{41}$ Unger, Roberto Mangabeira (1976) Law in Modern Society: Toward a Criticism of Social Theory, Free Press 1976. For some authors, the pervasiveness of legal instrumentalism undermines the "rule of law." See Tamanha, Brian (2006) Law as Means to an End: Threat to the Rule of Law Cambridge: Cambridge University Press.

${ }^{42}$ Green, Leslie (2010) 'Law as a Means' in Peter Cane ed, The Hart-Fuller Debate in the Twenty-First Century, Oxford: Hart Publishing, 169.

${ }^{43}$ Newton, Scott (2016) Law and the Making of the Soviet World: The Red Demiurge, Routledge.
} 
eradicate primordial identities. In fact, it was instrumentalised by different parties for other purposes than those originally intended. ${ }^{44}$

\section{The Incoherence of Constitutions:}

The label "ideological constitutions" to designate authoritarian modernisation is no less misleading than “instrumentalism." Consider, for instance, the Algerian constitutions that scholars frequently cite as examples of ideological constitutions. The first post-colonial constitution (1963) stated in the preamble that the revolutionary goals included improving women's status, eradicating illiteracy, and raising health and housing standards. The provisions on fundamental principles included Islam as the official religion and the establishment of a socialist democracy. It also subordinated the judiciary both to "law" and "to the interests of the socialist revolution" (article 62). The Algerian Constitution of 1976 stated that "the judiciary contributes to the defense of the achievements of the socialist revolution and to protecting its interests” (article 166). Article 173 similarly stipulated, that judges "shall contribute to the defence and the protection of the socialist revolution.”

Yet, these textual quotations do not sufficiently capture constitutional practice. First, Algeria lacked a working constitution between 1965 and 1976. The president suspended the constitution of 1963 for security reasons shortly after its ratification. Following Houari Boumediene’s military coup, the country was ruled without a formal constitution from 1965 to 1976, during which the government led the nationalization of the economy. This illustrates not merely the gap between text and enforcement, but also that "revolutionary legitimacy” may be manifested in written constitutional documents as much as in their absence. Algerian scholars label this period as one in which government was based on "revolutionary legitimacy," as opposed to “constitutional legitimacy” (1963-1965, and then again 1976-1996), in which government was based on legal and constitutional authorizations. ${ }^{45}$ Revolutionary legitimacy, then, may combine normative appeal and sociological compliance.

Second, there is a potential conflict between different constitutional provisions and norms. Article 173 of the 1976 Constitution added that judges "shall be protected against all forms of pressure, interference,

\footnotetext{
${ }^{44}$ Newton, The Constitutional Systems 79-80.

45 Uyahya, Al-Ifa (2004), Al-Nizam Al-Dusturi Al-Jaza'iri, 2nd edn., Al-Dar al-'Uthmaniyya li-l-Nashr wa-l-Tawzi', 69-70, 103-107.
} 
or maneuvers likely to undermine the accomplishment of their mission or the respect of their free will." Article 172 further stipulated, that judges "shall solely obey the law.” In other words, there is a potential for conflict between law and socialism, between maintaining judicial integrity/independence and between state diktat, or-more generally—between the requirements of "legality" and "revolution." These conflicts between the "rule of law" and "social transformation” were present in other revolutionary experiences such as the Soviet Union or Cuba in which legality became an institutional interest of the revolution. ${ }^{46}$ The manner in which these conflicts materialize and how they unfold cannot be assessed outside the context of legal and judicial practice. Whether in socialist or non-socialist states, courts develop the law and fill the gaps against the backdrop of these conflicts. ${ }^{47}$ The practice of socialist courts was not always consistent with pronouncements of socialist legality and presented conflicting views of the law under socialism. ${ }^{48}$

Thirdly, "socialism” is an abstract concept and as such it does not determine specific legal disputes or interpretative conflicts. In the "Enriched National Accord" of 1986, the Algerian regime explained that socialism is not "fixed" but rather a process (“a march”) to guarantee a fairer society, and that it is "totally consistent with Islam's call for the realization of social justice.” ${ }^{49}$ In any event, the subsequent Algerian 1989 and 1996 Constitutions omitted these references to the socialist revolution alongside the rise of the discourse of political pluralism, separation of powers, the rule of law, and institution-building. ${ }^{50}$

These ruptures, inconsistencies, ambiguities, and changes undermine the utility of “ideological” as an explanatory label. Nevertheless, some scholars problematically argue that the late-nineteenth-century constitutionalism was less "ideological" than the twentieth-century post-colonial constitutionalism. ${ }^{51} \mathrm{It}$ should be clear, however, that usage of the phrase "ideological constitutions" with respect to authoritarian constitutionalism should not imply a lack of "ideology" in either earlier (pre-independence) constitutions or

\footnotetext{
${ }^{46}$ Quigley, John (1989) 'Socialist Law and the Civil Law Tradition' 37(4) The American Journal of Comparative Law 781, 796; Michalowski, Raymond J. (1995) 'Between Citizens and the Socialist State: The Negotiation of Legal Practice in Socialist Cuba' 29(1) Law \& Society Review 65.

${ }^{47}$ Quigley, 'Socialist Law and the Civil Law Tradition' 792-93.

48 Markovits, Inga (1982) 'Law or Order: Constitutionalism and Legality in Eastern Europe' 34(3) Stanford Law Review 513 (referring in particular to the German Democratic Republic).

${ }^{49}$ Quoted in Uyahya, Al-Nizam Al-Dusturi Al-Jaza'iri 150.

50 Uyahya, Al-Nizam Al-Dusturi Al-Jaza'iri 155, 126-27, 349.

51 Brown, Constitutions in a Nonconstitutional World 32.
} 
in non-authoritarian constitutions elsewhere. The difference may be in degree (and visibility) but not in kind. $^{52}$

\section{The End of Ideology?}

In order to understand the misleading nature of the binary between "ideological" and "non-ideological" constitutions, it is imperative to recall that the state cannot be neutral in any constitution. The state is not completely separate from society and is not immune to social conflicts. Rather, the "state” and "society" are intertwined and mutually constitutive. ${ }^{53}$ Understanding the role of the state in liberal democratic and capitalist societies requires foregrounding permissions and not only prohibitions of the "rule of law." 54 The state is complicit in producing distributive consequences even when the ground rules—which condition the bargaining powers of differently situated parties and therefore determine winners and losers of legal regulation—are seemingly apolitical and technical. ${ }^{55}$ Additionally, the ubiquity of coercion in the private sphere, and not only in the public sphere, challenges notions of pre-existing "natural rights" and the distinction between state and "civil society." 56 The state is complicit in the coercion within the private sphere because property rights are not simply a relation between persons and things, but rather a relation between persons with respect to things. As such, they are a form of delegation of sovereignty-i.e., coercive public powers-to private actors because they empower property holders to shape others' lives. ${ }^{57}$ Furthermore, the distinction between the private and the public sphere is incoherent and indeterminate. ${ }^{58}$ Therefore, the market is not "free" because the state regulates it and shapes its outcomes in capitalist economies and not only in socialist and centralized economies. ${ }^{59}$ On the other hand, socialist theorists who initially rejected judicial review because they claimed that the state represented the common interest of workers, recognised that "the administration is never neutral" and may depart from the "interests of the

\footnotetext{
52 See, e.g., Tushnet, Mark (2015) 'Authoritarian Constitutionalism' 100 Cornell Law Review 391, 452.

${ }^{53}$ Jessop, Bob (2014) The State: Past, Present, Future, Cambridge: Polity, 54, 89.

${ }^{54}$ Hohfeld, Wesley (1913) 'Some Fundamental Legal Conceptions as Applied in Judicial Reasoning' 23(1) Yale Law Journal 16; Singer, Joseph (1982) 'The Legal Rights Debate in Analytical Jurisprudence from Bentham to Hohfeld' Wisconsin Law Review 976.

55 Kennedy, Duncan (1991) 'The Stakes of Law, or Hale and Foucault!' 15 Legal Studies Forum 327; Kennedy, Duncan (2002) 'The Political Stakes in "Merely Technical” Issues of Contract Law' 10 European Review of Private Law 7.

${ }^{56}$ Hale, Robert (1923), 'Coercion and Distribution in a Supposedly Non-Coercive State' 38 Political Science Quarterly 470.

${ }^{57}$ Cohen, Morris (1933) 'Property and Sovereignty' in his Law and the Social Order: Essays in Legal Philosophy, Hamden, Conn.: Archon Books. For an application of this analysis to the context of Egypt, see Mitchell, Timothy (2002), Rule of Experts: Egypt, Techno-Politics, Modernity, University of California Press, 70-74.

${ }^{58}$ Kennedy, Duncan (1982) 'The Stages of the Decline of the Public/Private Distinction' 130 University of Pennsylvania Law Review 1349.

${ }^{59}$ Hale, 'Coercion and Distribution' 478, 481.
} 
represented class.”60 These insights undermine the overly drawn distinction between "ideological” and "nonideological” constitutions.

It is insufficient, then, to focus on formal declarations (law-in-the-books) and ignore the law-inaction because judges make the law and do not mechanically apply it. ${ }^{61}$ The distinctions between adjudication and legislation, rights and policy, law and politics, or the rule of law and rule of men are overstated. Nor is it enough to focus on public law and ignore private law. The focus on "constitutionalisation and centralisation of state power" may obscure "the complex and mediated ways in which power circulates within and beyond the state.”62 In particular, the emphasis on formal institutional modes of representation conceals the informal ways. ${ }^{63}$

Thus, it is equally misleading to use the phrase "de-ideologisation" for post-authoritarian constitutions. ${ }^{64}$ Such terminology seems to fit the liberal claim (combining liberal rights and market economy) to represent the neutral or universally agreed background. Thus, its invocation implies the "end of ideology" or the "end of history" after the cold war and the absence of credible alternative institutional designs to political and economic liberalism. In this case, any "ideological” constitution becomes a deviation from the norm, which is wrongly dubbed as "non-ideological.”

The source of confusion here is not defining ideology simply as a system of ideas or an expression of the "nature of the political community." ${ }^{65}$ If that were the case, a typology of constitutions as an expression of political ideas would include: liberal-democratic; liberal non-democratic; non-liberal democratic; welfare state; and socialist constitutions. ${ }^{66}$ Nor does the inclusion of Islamic law in a constitution make it more ideological than seemingly secular constitutions. ${ }^{67}$ Instead, the problem is with the additional implicit claim that only one type of system of ideas is distinctively "ideological," whereas another is not, that is in itself "ideological." Here it is useful to invoke the critical sense of "ideology": a system of ideas that

\footnotetext{
${ }^{60}$ Ludwikowski, Rhett (1988) 'Judicial Review in the Socialist Legal System: Current Developments' 37(1) International and Comparative Law Quarterly 89.

${ }^{61}$ Pound, Roscoe (1910) 'Law in Books and Law in Action' 44 American Law Review 12.

62 Jessop, The State 57.

63 Jessop, The State 61.

${ }^{64}$ Arjomand, 'Constitutional Development and Political Reconstruction' 18.

65 See, e.g., Brown, Constitutions in a Nonconstitutional World 11.

${ }^{66}$ Grimm, Dieter (2012) "Types of Constitutions" in Rosenfeld, Michel and Sajó, András eds, The Oxford Handbook of Comparative Constitutional Law, Oxford: Oxford University Press 98.

${ }^{67}$ See, generally, Sultany, Nimer (2013) 'Against Conceptualism: Islamic Law, Democracy, and Constitutionalism in the aftermath of the Arab Spring' 31 Boston University International Law Journal 435; Sultany, Nimer (2014) 'Religion and Constitutionalism: Lessons from American and Islamic Constitutionalism' 28(1) Emory International Law Review 345.
} 
misrepresents the world to citizens in a certain way that would reconcile them with the institutional arrangements under which they live because they are legitimated as “natural” or "necessary” or "just.”68

As an "ideology" (in the critical sense), the categorization of "ideological” (in the "positive” sense, i.e. political and substantive) constitutions conceals more than it reveals. It glosses over differences within the "ideological” group of constitutions. It assumes a coherence that hardly exists, and lumps together too many "ideological constitutions" notwithstanding their varying normative status and efficacy. This is due to the absence of a discussion of constitutional practice, including judicial applications and interpretations.

\section{FROM TEMPORARY TO PERMANENT CONSTITUTIONS}

Another formal distinction that hinders a better understanding of the legitimating role of constitutions is the one between "temporary” and "permanent” constitutions. The temporary aspect of many Arab constitutions highlights the link between stability and normative status. On the one hand, a "temporary" or "transitional" constitution implies a lack of durability and stability that may be instrumental in the development of effective legal institutions. On the other hand, it suggests that the constitution is subordinated to political expediency and thus lacks the supremacy required for its normative legitimacy. Thus, the temporariness of Arab constitutions may be considered as an indicator of a weak normative foundation. Nevertheless, a weak normative status cannot be deduced solely from the temporary characteristic. The normative desirability of stability is contested and is contingent on the specific context in which constitutions operate.

\section{What good is stability?}

Those who value formal constitutional stability suggest that temporariness is a contradictory notion that is likely to undermine good and stable governance. Tom Ginsburg, for instance, argues that stability is a necessary attribute for a constitution because it is likely to provide a stable basis for politics, encourage obedience to the law, allow the development of intermediary institutions, and prevent opportunism via

\footnotetext{
${ }^{68}$ Geuss, Raymond (1981) The Idea of a Critical Theory: Habermas \& the Frankfurt School, Cambridge: Cambridge University Press; Shelby, Tommie (2003), 'Ideology, Racism, and Critical Social Theory’ 34 Philosophical Forum 153.
} 
frequent change of the rules of the game. ${ }^{69}$ It is thus assumed that stability is a good, and consequently constitutional design needs to maximize it.

Yet, competing considerations may justify sacrificing formal constitutional stability and efficiency of constitutional design. Indeed, temporary constitutions can be an antidote to the fetishism of constitutions and the rigidity of entrenched constitutions, as well as a recognition of the incremental nature of constitutional development. ${ }^{70}$ In particular, during "transitional” times and following regime change a "transitional" constitution may lower the stakes of constitution-making, facilitate agreement, and prevent conflict. ${ }^{71}$ In theory, the advantages of temporary constitutions may include:

(1) promoting incrementalism and experimentation where error costs are high, (2) reducing cognitive biases where cognitive biases predominate in constitutional design, (3) facilitating consensus building where decision costs are high, and (4) relaxing the 'dead hand' problem by easing intertemporal control by the constitutional framers. ${ }^{72}$

Thus, temporariness in itself is not necessarily normatively objectionable. Additionally, formal constitutional durability is not descriptively informative. Instead, a more rewarding inquiry would place these constitutions within the legal and political "totality,” namely larger processes of state formation and a complex web of legitimation. In many cases, the legitimacy problem is systemic and not reducible to the temporary constitutional documents. In post-1952 Egypt, for instance, the revolutionary regime enacted several, shortlived, temporary, and largely ineffective constitutions. ${ }^{73}$ Revolutionary legitimacy and personal legitimacy of leaders engaged in large-scale transformative projects weakened constitutional legitimacy, as many were simply acts of executive power and without popular ratification. ${ }^{74}$ The regime often violated its own constitutionally prescribed procedural requirements, ${ }^{75}$ and took actions without legal authorization. ${ }^{76}$ The process of bureaucratization and centralization of state power simultaneously undermined the prospect of

\footnotetext{
${ }^{69}$ Ginsburg, Tom (2011) 'Constitutional Endurance' in Ginsburg, Tom and Dixon, Rosalind eds, Comparative Constitutional Law, Edward Elgar Publishing 112.

70 Varol, Ozan O. (2014) 'Temporary Constitutions' 102 California Law Review 409, 412.

71 Jackson, Vicki C. (2008), 'What's in a Name? Reflections on Timing, Naming, and Constitution-making' 49 William \& Mary Law Review 1249, 1252-53, 1305.

72 Varol, 'Temporary Constitutions' 414.

73 Between 1952 and 1970 Egypt had six constitutions or constitutional declarations as well as eleven cabinets. Al-Bishri, Tariq (1987) Al-Dimuqratiyya wa Nizam 23 Yuliu 1952-1970, Beirut: Mu'assasat Al-Abhath Al-'Arabiyya, 111.

${ }^{74}$ Al-Bishri, Al-Dimuqratiyya 109.

75 Al-Bishri, Al-Dimuqratiyya 110.

76 Al-Bishri, Al-Dimuqratiyya 160--62.
} 
separation of powers and empowered the military and security apparatus. ${ }^{77}$ State constitutions and law granted the president wide-ranging powers and an expansive immunity and hence sanctioned the personalization of decision-making power. ${ }^{78}$ Accordingly, the growth of personal leadership went hand-inhand with the weakening of state institutions. ${ }^{79}$

In other cases, like Iraq’s Interim Constitution of 1970, the constitution is problematic because of the institutional design it reflects rather than its temporariness. Specifically in the Iraqi case, the temporary constitution concentrated legislative and executive powers in a "Revolutionary Command Council." It considerably limited the powers and the independence of the legislative branch. Ordinary legislation initially made membership in the parliament dependent upon appointment by the Revolutionary Command Council. It then required in 1980 an electoral process but crippled it with strict eligibility requirements. ${ }^{80}$

In other cases, the problem is the lack of implementation of the constitution because of the weakness of state structures and a prevalent anti-constitutionalist ideology. The Libyan temporary Constitutional Declaration of 1969 that followed the overthrow of the monarch did not lead to a permanent constitution, nor was it implemented. ${ }^{81}$ It was never formally repealed and hence it was not really temporary, notwithstanding its formal designation. Its irrelevance increased over time as it was displaced by other documents and legislation. ${ }^{82}$ Moreover, the revolutionary regime’s practice undermined notions of constitutionalism and rule of law because Qadhafi's thought expressed a clear anti-constitutionalist strand. ${ }^{83}$

These three examples suggest the futility of overemphasizing formal temporariness because it is not necessarily informative of the political order's systemic malaise. There are two additional reasons for the deficiency of the label. First, formal constitutional stability differs from political stability. On the one hand, lack of formal constitutional durability does not necessarily imply political instability in authoritarian regimes. Provisional constitutions may reflect political changes in a stable regime, such as Egyptian constitutional changes that followed the formation and dissolution of the unity between Egypt and Syria

\footnotetext{
77 Al-Bishri, Al-Dimuqratiyya 105, 108, 122, 166-68.

78 Al-Bishri, Al-Dimuqratiyya 93, 108, 126

${ }^{79}$ Al-Bishri, Al-Dimuqratiyya 150.

${ }^{80}$ Al-Ali, Zaid (2012), 'Constitutional Legitimacy in Iraq: What Role Local Context?' in Grote, Rainer and Röder, Tilmann J. eds, Constitutionalism in Islamic Countries: Between Upheaval and Continuity Oxford: Oxford University Press, 635, 644-45. 81 Mezran, Karim (2012), 'Constitutionalism and Islam in Libya' in Grote, Rainer and Röder, Tilmann J. eds, Constitutionalism in Islamic Countries: Between Upheaval and Continuity, Oxford: Oxford University Press, 513, 525-26.

82 Mezran, 'Constitutionalism and Islam in Libya' 528.

83 Mezran, 'Constitutionalism and Islam in Libya' 529-31.
} 
(1958-1961). On the other hand, constitutional instability in the form of a constitutional rupture may follow from political continuity as much as from change. A successful coup (Algeria 1965) or a failed coup (Morocco 1971) may lead to the suspension of the constitution (Algeria’s 1963 Constitution and Morocco’s 1970 Constitution). ${ }^{84}$ Thus, constitutional rupture may occur even if no political rupture occurred.

Second, the effect of political stability on normativity is indeterminate. Stability may undermine the normative prospects of the constitution no less than instability. The very stability of the authoritarian regime may preclude recourse to enacting a constitution that reflects a compromise. In this sense, a temporary postcolonial constitution may be weaker than the nineteenth-century constitutions or twentieth-century colonial constitutions that rested on a compromise, not because it is temporary but because it lacks the grounding of a broad political basis. ${ }^{85}$

\section{Collapsing the distinction}

It follows from the above that temporariness is neither normatively objectionable, nor sociologically informative, nor determinative of the constitution's normative value. Thus, the distinction between constitutional temporariness and permanence does not fit the richness of Arab constitutional practice because none of the attributes ascribed to either side of the distinction is an exclusive distinctive marker.

A temporary constitution does not necessarily differ from a permanent constitution in its form or the substantive issues it addresses. In fact, a temporary constitution may be formally entrenched (as in the 1964 Egyptian Constitution). ${ }^{86}$ Some of its provisions may also be substantively entrenched and thus arguably unamendable (like "republicanism” in Egypt's 1956 Constitution). ${ }^{87}$ On the other hand, a permanent constitution may be formally entrenched but nevertheless in practice easily amended. Constitutional rigidity and flexibility is not a formal matter but is contingent upon the political context. ${ }^{88}$ Tunisia's 1959 Constitution required two readings in parliament and a two-thirds majority in both readings. The reality of a presidential system and a dominant ruling party made this high threshold easy to surpass. Parliament

\footnotetext{
${ }^{84}$ See, e.g., Ghallab, Abd al-Karim (1988), Al-Tatawwur al-Dusturi wa-l-Niyabi bi-l-Maghrib, 1908-1988, Matba'at al-Najah al-Jadida, 227 (discussing Morocco).

${ }^{85}$ Farahat and Farahat, Al-Tarikh al-Dusturi al-Misri 65 (maintaining that Egypt's 1956 temporary constitution reflected neither a compromise nor a minimal consensus).

${ }^{86}$ Badawi, Tharwat (1969), Al-Qanun al-Dusturi wa-Tatawwur al-Anzima al-Dusturiyyah fi Misr, Dar al-Nahda al-'Arabiyya, 312.

${ }^{87}$ Laylah, Muhammad Kamil (1967), Al-Qanun al-Dusturi, Matba'at al-Nahda al-Jadida, 86-88.

88 Negretto, Gabriel L. (2012), 'Replacing and Amending Constitutions: The Logic of Constitutional Change in Latin America' 46(4) Law \& Society Review 749, 760.
} 
amended the constitution sixteen times between 1959 and 2008. Many of these reflected political expediency and thus undermined the status of the constitution as a supra-political document standing above the foray of politics. ${ }^{89}$ A 1997 amendment added the option of amending the constitution through referenda. Yet, this too proved easy to surpass in a non-democratic regime: a 2002 constitutional referendum won more than 99 percent of the vote. Independent observers described this result as a "sham." 90 The 2002 amendment is particularly interesting given its comprehensiveness: it amended thirty-nine out of seventy-eight articles in the constitution. ${ }^{91}$ Nevertheless, President Ben Ali chose continuity through the amendment procedure rather than declaring a new constitution. In such a case, the permanent constitution looks like a series of flexible, temporary constitutions. Formal constitutional continuity simply obfuscates the reality of change.

One could also take issue with approaches that highlight a primary difference between temporary and permanent constitutions with reference to the circumstances of establishment (which rulers consider as “exceptional” or "transitional”) and the method of enactment of constitutions (which generally eschews constituent assemblies and referenda). ${ }^{92}$ The significance of these differences should not be overstated. Although the permanent constitution's enactment process may differ from the temporary constitution's process, this difference may not amount to more than a formality under non-democratic regimes. A constituent assembly did not enact Egypt's 1971 Constitution, and the process of popular ratification was of questionable legitimacy as it was not preceded by an ample popular and free discussion, and was clouded by suspicions of voting engineering. ${ }^{93}$

Likewise, the distinction between temporary and permanent is suspect. On the one hand, the prolongation of the "transitional" period undermines the distinction. On the other hand, all constitutions are provisional. Whereas in the case of Tunisia’s 1959 Constitution the permanent looks temporary, in the cases of Egypt, Iraq, and Libya, the transitional became permanent. In Algeria, the frequent enactment of “permanent” constitutions — and their subsequent amendments—reflected “crisis constitutions,” and

\footnotetext{
89 Ben Achour, Rafaa (2009), Al-Mu'assasat wa-l-Nizam al-Siyasi bi-Tunis (Al-Itar al-Tarikhi - Al-Nizam al-Hali), 2nd edn, Markaz al-Nashr al-Jami'I, 118-29; Ben Achour, Rafaa (2000), 'Himayat al-Dustur' in Al-Dustur al-Tunisi fi al-Dhikra alArba'in li-Isdarihi 1959-1999, Markaz al-Dirasat wa-l-Buhuth al-Iqtisadiyya wa-l-Ijtima'iyya, 187, 194 (fn. 7). Most of these amendments concerned the legislative branch. Chaabane, Naila (2000), 'Al-Dustur wa-l-Sulta al-Tashri'iyya' in Al-Dustur alTunisi fi al-Dhikra al-Arba'in li-Isdarihi 1959-1999, Markaz al-Dirasat wa-l-Buhuth al-Iqtisadiyya wa-l-Ijtima'iyya, 89, 9092.

90 BBC, 'Win confirms Tunisia leader in power' (27 May 2002).

91 al-Marzuqi, Salim Karir (2005), Al-Tanzim al-Siyasi wa-l-Idari al-Tunisi fi Jumhuriyat al-Ghad, Maktabat al-Manar, 68.

92 As argued in Badawi, Al-Qanun al-Dusturi 296-98.

${ }^{93}$ Farahat and Farahat, Al-Tarikh al-Dusturi al-Misri 41, 70.
} 
Algerian constitutional history can be read as a "search for a permanent constitution." 94 In all these cases, whether permanent or temporary, internal and external political realities shaped constitutional changes.

The difference in normative power between the temporary and permanent constitutions may be one of degree rather than kind. On the one hand, courts may still exercise a power of judicial review of administrative and legislative acts based on a temporary constitution (as in the case of the 1956 Egyptian Constitution). ${ }^{95}$ On the other hand, the move to a permanent constitution does not necessarily lead to a significant constraint on executive power. As Sadat consolidated power, the move to the 1971 permanent constitution signified a desire to stabilize the regime and to move away from the extended post-revolutionary transitional period. The constitution encroached upon freedom of speech, granted expansive powers to the president, limited the parliament's ability to make authorities accountable, and undermined the separation of powers. ${ }^{96}$ Moreover, a permanent constitution may include no fewer gaps and ambiguities than a temporary constitution. The 1971 Constitution contained substantial ambiguities and left many issues related to identity, rights protection, and institutional design for elaboration (or derogation) through ordinary legislation. Ambiguity and deferral are often considered a vice in temporary constitutions but a virtue in permanent constitutions as they may help constitutions endure and stabilize. Yet, the success of this deferral depends on the context in which the constitution is operationalized. ${ }^{97}$

To conclude, the distinction between "temporary" and "permanent" constitutions is analytically tenuous, descriptively misleading, and normatively suspect. The realization of the normative potential of a constitution depends on a host of institutional and sociological considerations that are not explicable simply by reference to the formal label "temporary” or "permanent."

\section{CONCLUSION}

The preceding arguments sought to collapse prominent distinctions within constitutional law and theory. Collapsing distinctions does not mean that two the categories are identical and that one should not

\footnotetext{
${ }^{94}$ Abbes, Ammar (2014) 'Al-Ta'dilat al-Dusturiyya fi al-Jaza'ir min al-Ta'dil al-Juz'i ila al-Islah al-Dusturi al-Shamil, Dirasa li-Ijra'at al-Ta'dil al-Qadim wa Madmunuhu' 12 Al-Acadimiyy li-l-Dirasat al-Ijtima 'iyya wa-l-Insaniyya 96, 98.

95 Laylah, Al-Qanun al-Dusturi 168-69, 594-95.

96 Farahat and Farahat, Al-Tarikh al-Dusturi al-Misri 87, 131-34.

${ }^{97}$ Lombardi, Clark B. (2013) 'The Constitution as Agreement to Agree: The Social and Political Foundations (and Effects) of the 1971 Egyptian Constitution' in Galligan, Dennis and Versteeg, Mila eds, The Social and Political Foundations of Constitutions, Cambridge: Cambridge University Press.
} 
prefer one over the other. It rather illustrates that an alleged distinctive marker that is attributed to one side of the distinction is also present in the opposing side. In other words, collapsing the distinction suggests that the difference is overstated; it is one of degree rather than kind. This is not an argument against making analytical distinctions either. It is rather an argument against the simplifying assumptions that accompany the deployment of these distinctions and the objectionable normative effects that follow from their deployment. Finally, it is not argument against abstractions per se, but rather it is an argument against bad abstractions.

Authoritarian constitutionalism may be understood as a category that seeks to identify a working of government that is especially objectionable. Yet, in the hands of many constitutional lawyers and political scientists it risks lulling the mind of the defects of liberal constitutional orders by making them look qualitatively different from other so-called authoritarian constitutions. Like a host of other dichotomies in comparative law and politics, the distinctions discussed here risk oversimplifying historical experiences and reinforcing the ethnocentrism of the comparativist. ${ }^{98}$ Accordingly, liberal constitutionalism becomes the standard by which the authoritarian constitution is measured, and the critique of authoritarian constitutions reaffirms the superiority of liberal constitutions. Yet, for these criticisms to be illuminating they need to be more cognizant of the actual practice of liberal and non-liberal constitutional systems alike. Idealising the liberal practice and discounting the non-liberal practice would lead to misguided conclusions.

Constitutional normativity cannot be deduced simply from a textual reading of the constitutional document or even from the intentions and motivations of the rulers and drafters of the texts. As such, a proper understanding avoids the de-contextualisation of these constitutions and rejects a formalist understanding that would portray their weakness as inherent to the document and simply because of the “strategic”, “ideological”, “instrumental”, or "temporary” design of the rulers. The objection is not that constitutions are not open to strategic, instrumental, and ideological uses. All constitutions are. Rather, the objection is to the formalist-textualist deployment of these labels and the implications that scholars seek to deduce from them with respect to legitimacy and constitutionalism. This formalist understanding would

\footnotetext{
98 Frankenberg, Günter (1985) 'Critical Comparisons: Re-thinking Comparative Law' 26(2) Harvard International Law Journal 411; Frankenberg, Günter (2016) Comparative Law as Critique, Cheltenham: E. Elgar.
} 
reduce the role of the judiciary into a mechanical application of the document, thus denying their agency and absolving them from complicity.

Moreover, these institutional weaknesses cannot also be simply explained by the overarching label "authoritarian" given the differences between states, regimes, and leaders. In this sense, authoritarian constitutionalism is both an under-inclusive and over-inclusive category. It is under-inclusive when it excludes from view the persistence of “constitutional dictatorship" in Western liberal democracies, ${ }^{99}$ and the structural democratic deficiencies of the liberal democratic order, whether it is the Senate in the U.S., the House of Lords in the UK, unaccountable and unelected federal judiciary, or the rise of "juristocracy" in both domestic and trans-national law to limit the power of majorities and insulate policy preferences from electoral competition. ${ }^{100}$

It is also under-inclusive in cases like Egypt when a period in which the country fell under British colonial occupation and was thus unfree is nevertheless labeled "the liberal period" because it included electoral competition under a monarchical constitution. This labeling obscures the ways in which the British violated individual liberties and repeatedly undermined the constitutional order and the "rule of law." On the other hand, post-colonial regimes such Nasser's that achieved independence, abolished the monarchy, expressed peoplehood, and expanded the franchise, but did not have free and fair elections, are labeled as authoritarian.

It is over-inclusive because it neutralises the difference between different rulers within the category when it lumps together many types of leaders and regimes. Such a label thus implies that right-wing and leftwing leaders are equally objectionable and that liberalism stands at an equal distance from them. In this sense, Egypt's presidents Nasser and Sadat are both considered authoritarian, and the constitutions they established during their rule are, accordingly, authoritarian constitutions. This uncritical labeling neutralises the difference between Nasser, the left-wing socialist leader who lifted millions from poverty, and Sadat, the

\footnotetext{
99 Balkin, Jack M. and Levinson, Sanford (2010) 'Constitutional Dictatorship' 94 Minnesota Law Review 1789; Rossiter, Clinton L. (2002 [1948]) Constitutional Dictatorship: Crisis Government in the Modern Democracies, New Brunswick: Transaction Publishers; Watkins, Frederick M. (1940) 'The Problem of Constitutional Dictatorship', in Friedrich, C.J. \& Mason, Edward S. eds, Public Policy, Cambridge, MA: Harvard University Press.

${ }^{100}$ Levinson, Sanford (2006) Our Undemocratic Constitution: Where the Constitution Goes Wrong (and How We the People Can Correct It), New York: Oxford University Press; Sabato, Larry J. (2007) A More Perfect Constitution: 23 Proposals to Revitalize Our Constitution and Make America a Fairer Society, New York: Walker Publishing Company; Hirschl, Ran (2004) Towards Juristocracy: The Origins and Consequences of the New Constitutionalism, Cambridge, MA: Harvard University Press; Nicol, Danny (2010) The Constitutional Protection of Capitalism, Oxford: Hart Publishing; Schneiderman, David (2000) 'Investment Rules and the New Constitutionalism' 25(3) Law \& Social Inquiry 757.
} 
right-wing leader who liberalised the economy, redistributed wealth upwards to the benefit of the upper classes, and sought to Islamize the constitutional order. It neutralizes the difference between the former who sought national sovereignty including over the economy, and the latter who plunged Egypt into political and economic dependency on the U.S. Finally, it erases the difference between a genuine republican leader and a mere populist or demagogue. This neutralisation of the difference illustrates that, instead of futile and uninformative generalizations, what is needed is an inquiry into who is doing what and why.

To conclude, these inclusions and exclusions illustrate that prominent scholarly distinctions have framing effects. This chapter, thus, is a plea for a more nuanced study of constitutional experiences that takes non-European and non-North American constitutions more seriously, and examines Western European and North American constitutions more critically. 